\title{
Evaluation of the Cariogenic Potential and Total Antioxidant Capacity of Saliva after the Consumption of Candies and Paneer: An In Vivo Study
}

\author{
Tanvi J. Shah ${ }^{10}$ Manju R. ${ }^{2}$ Aum B. Joshi ${ }^{3}$ Ngangbam Reenayai ${ }^{4}$ (1) \\ 1 Pediatric Dentist, Mumbai, Maharashtra, India \\ 2 Department of Pediatric and Preventive Dentistry, Attavar Balakrishna \\ Shetty Memorial Institute of Dental Sciences, Nitte (Deemed to be \\ University), Derelakatte, Mangalore, Karnataka, India \\ ${ }^{3}$ College of Dental Sciences, Amargadh, Gujarat, India \\ ${ }^{4}$ Department of Pediatric and Preventive Dentistry, Attavar \\ Balakrishna Shetty Memorial Institute of Dental Sciences, \\ Derelakatte, Mangalore, Karnataka, India \\ J Health Allied Sci ${ }^{\mathrm{NU}}$ 2022;12:427-440. \\ Address for correspondence Manju R., MDS, PhD, Department of \\ Pediatric and Preventive Dentistry, Attavar Balakrishna Shetty \\ Memorial Institute of Dental Sciences, Nitte (Deemed to be \\ University), Derelakatte, Mangalore 575018, Karnataka, India \\ (e-mail: drmanjupedo@gmail.com).
}

\begin{abstract}
Keywords

- candies

- paneer

- $\mathrm{pH}$

- calcium

- phosphorus

- alkaline phosphatase

- total antioxidant capacity

Aim The present study was performed to assess and compare the changes in $\mathrm{pH}$, calcium, phosphorus, alkaline phosphatase, and the total antioxidant capacity (TAC) of saliva after consuming candies, followed by rinsing with water and consumption of paneer.

Materials and Methods Baseline saliva of $5 \mathrm{~mL}$ was collected from 60 children and they were asked to chew on candies. After 10 minutes of intake of candies, $5 \mathrm{~mL}$ of saliva was collected. They were then divided into two groups of 30 each and test products were given. Group 1: rinse with water and group 2: chew $20 \mathrm{~g}$ of paneer and swallow. Saliva of $\% \mathrm{~mL}$ was collected after 10, 20, and, 30 minutes from the study groups. The saliva samples collected were assessed for $\mathrm{pH}$, calcium, phosphorus, alkaline phosphatase, and TAC. The data were analyzed using the paired $t$-test and post hoc Tukey's test.

Results The $\mathrm{pH}$, calcium, phosphorus, and alkaline phosphatase decreased from baseline values after consuming candies significantly $(p<0.001)$. These increased after rinsing with water and consumption of paneer which was statistically significant $(p<0.001)$. The TAC values increased significantly after consuming candies and decreased after rinsing with water and consumption of paneer which was substantial for both the groups.

Conclusion Consumption of candies created a cariogenic milieu. Both the study groups were effective in the reversal of the cariogenic potential. The consumption of paneer caused remineralizing properties and showed superior results than rinsing with water.
\end{abstract}

published online

February 25, 2022
DOI https://doi.org/ $10.1055 / \mathrm{s}-0042-1743191$. ISSN 2582-4287. (c) 2022. Nitte (Deemed to be University). All rights reserved. This is an open access article published by Thieme under the terms of the Creative Commons Attribution-NonDerivative-NonCommercial-License, permitting copying and reproduction so long as the original work is given appropriate credit. Contents may not be used for commercial purposes, or adapted, remixed, transformed or built upon. (https://creativecommons.org/ licenses/by-nc-nd/4.0/)

Thieme Medical and Scientific Publishers Pvt. Ltd., A-12, 2nd Floor, Sector 2, Noida-201301 UP, India 


\section{Introduction}

Dental caries, a common chronic childhood disease, ${ }^{1}$ is initiated by consuming fermentable carbohydrates which are converted into organic acids by the cariogenic bacteria in dental plaque. These acids cause a fall in the salivary $\mathrm{pH}$ and result in demineralization by removing calcium and phosphate ions from the enamel subsurface. ${ }^{2}$

The 20th century has brought about a significant change in the dietary habits of children. Different types of chocolates are available in the market, and their frequent consumption has resulted in rampant caries at a very early age. The mean prevalence of dental caries in India for age group 5 and 12 years was $49 \%$ and for age 15 years was $60 \%{ }^{3}$ and those consuming substances containing sugar were at a 4.8 times higher risk. ${ }^{4}$ Cariogenicity in terms of $\mathrm{pH}$ and salivary clearance of commercially available chocolates has been studied $^{5,6}$ and candies with increased sucrose content, higher frequency of intake, and delayed clearance were more cariogenic. ${ }^{5,6}$ There is a lack of data evaluating in vivo changes in the salivary parameters like calcium, phosphorus, alkaline phosphatase, and total antioxidant capacity (TAC) after consuming candies.

The cariogenic potential of food is related to the retention time of the acidic carbohydrates in the mouth, the role of saliva in oral clearance, the presence of remineralizing ions like calcium and phosphorus, and its buffering capacity. ${ }^{7}$ Research has shown that reduced calcium, phosphorus, and $\mathrm{pH}$ levels are associated with a higher prevalence of caries. ${ }^{8,9}$ Saliva has various protective antioxidant mechanisms which prevent formation of free radicals and repair oxidative damage caused by bacteria. Imbalance in levels of free radicals, reactive oxygen species, and antioxidants in saliva play an essential role in the onset and development of dental caries. ${ }^{10}$

Salivary calcium and phosphorus diffuse into the subsurface at the early stages of demineralization, causing a reversal. ${ }^{11}$ Also, alkaline phosphatase, a nonspecific phosphomonoesterase, helps in producing free inorganic phosphate which provides ions for remineralization by common ion effect. ${ }^{12}$ However, in children with high caries risk, due to repeated or increased exposure to cariogenic food, the salivary defense mechanism is not adequate and they require additional sources of these ions.

Diet counseling has been emphasized to prevent or reduce decay, ${ }^{13}$ with limitation of sugar intake being the key objective. However, lack of patient compliance renders this concept ineffective, creating a need for an alternative solution. Traditionally, it was thought that rinsing with water after the consumption of sucrose helped in oral clearance and elimination of the cariogenic challenge, its effect on various salivary parameters remains unknown.

There is also an increasing amount of data regarding the emerging role of milk and milk products in preventing dental caries and promoting remineralization. ${ }^{14-16}$ Apart from being natural, the benefits of milk are due to the presence of casein phosphopeptides, proteins, fats, vitamins, calcium, and phosphate. ${ }^{15}$ Lactoferrin and casein in milk and milk products inhibit the adherence of bacteria. ${ }^{17}$
Major emphasis has been placed on the anticariogenic properties of milk products, like paneer, which are economical and common constituents of the Indian diet. They cause saliva stimulation, enhancing their buffering capacity, and faster carbohydrate clearance. ${ }^{18-21}$ They are also rich in proteins like casein, calcium, and phosphorus. Paneer or Indian cottage cheese is unsweetened, an unripened form of cheese with lesser content of fatty acids and preservatives than commercial cheese. ${ }^{22}$ However, there are limited data on the antioxidant properties of dairy products like paneer. Hence, this study was undertaken to assess the efficacy of this diary product to counteract the cariogenic challenge of sweetened candies.

\section{Materials and Methods}

A comparative study was conducted at Attavar Balakrishna Shetty Memorial Institute of Dental Sciences, Nitte (Deemed to be University), Mangaluru, Karnataka, India. Sixty children between the age group of 5 to 12 years who reported for dental treatment to the Outpatient Department of Pediatric and Preventive Dentistry were included in the study. The sample size estimation was calculated using the following formula:

$$
n=\frac{2\left(Z_{a}+Z_{1-\beta}\right)^{2} \sigma^{2}}{\Delta^{2}}
$$

Normal children, who do not have any systemic or metabolic disease and special health care needs with decayed missing filled teeth (DMFT)/deft 3 to 5 , were included in the study according to the World Health Organization (WHO) criteria.

Caries-free children, children with teeth having enamel defects, children on medication due to any systemic and metabolic diseases, and children with special health care needs were excluded from the study. In addition, clearance from the Institutional Ethics Committee (reference no.: ABSM/EC/75/2013) was obtained.

According to the WHO criteria, patients were screened using mouth mirror and probe, and children with active caries were selected for the study. In addition, the study was explained to the parents and the patients, and written consent from parents/guardians and verbal assent of the child was obtained.

Oral prophylaxis was done 24 hours before the study to maintain standardization. Patients were asked to refrain from brushing on the day of salivary sample collection and eating or drinking 2 hours before the examination. In addition, $5 \mathrm{~mL}$ of baseline unstimulated saliva was collected by making the child sit in "Coachman's position" at the edge of the chair and passively drooling saliva in sterilized plastic containers. This saliva sample was analyzed for $\mathrm{pH}$, calcium, phosphorus, alkaline phosphatase, and TAC.

All Children were given one sweetened candy, and they were asked to suck on it till they finished it. The children took approximately 5 minutes to complete the entire candy. Saliva sample of $5 \mathrm{~mL}$ was collected after 10 minutes of candy consumption by the method as mentioned above.

The patients were then randomly divided into two groups of 30 each. Group 1: rinse with water and group 2: chew on 20-g paneer and then swallow it. 
Saliva of $5 \mathrm{~mL}$ sample was then collected by the same method at 10-, 20-, and 30-minute intervals after the consumption of water and paneer. The patients were later asked to brush thoroughly to remove any candy particles adhering to the tooth. The salivary samples were stored at $-20^{\circ} \mathrm{C}$ till the biochemical analysis was performed. All the collected saliva samples were centrifuged at 3,000 rpm for 10 minutes, and the supernatant was used for biochemical analysis. Supernatant saliva was analyzed for $\mathrm{pH}$, calcium, phosphorus, alkaline phosphatase, and TAC.

The biochemical methods used to analyze salivary $\mathrm{pH}$, calcium, phosphorous, and alkaline phosphatase were digital $\mathrm{pH}$ meter, modified o-Cresolphthalein complexone (OCPC) method, phosphomolybdate method, and Deutsche Gesellschaft Fur Klinische Chemie - Scandinavian Society of Clinical Chemistry (DGKC-SCE) method, respectively. TAC was measured by phosphomolybdenum method and analyzed by spectrophotometer.

\section{Statistical Analysis}

Paired $t$-test was used to analyze the changes in salivary parameters at baseline; 10 minutes after the consumption of candies; and 10,20, and 30 minutes after water and paneer. The level of significance was set at $p<0.05$. In addition, evaluation of intergroup changes in the salivary parameters from candies and at 10-, 20-, and 30-minute intervals after the intake of water and paneer was analyzed by post hoc Tukey's test.

\section{Results}

\section{pH}

The mean baseline $\mathrm{pH}$ of saliva decreased after consuming candies and increased steadily in group I from 10, 20, to

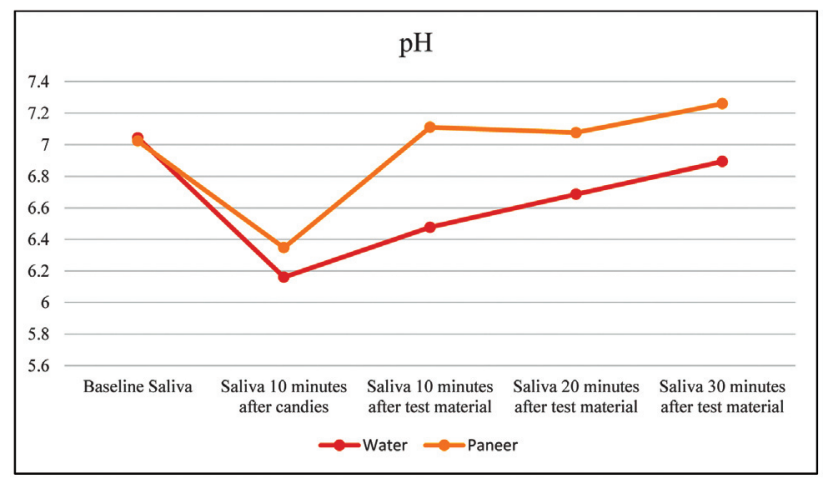

Fig. 1 The pH levels in saliva at baseline, after consumption of candies followed by water and paneer at different time intervals.

30 minutes which was highly significant $(p<0.001)$. However, the final mean $\mathrm{pH}$ after 30 minutes was lower than the baseline. This difference was highly significant $(p<0.001 ;$ - Table 1; - Fig. 1$)$.

The reduction in the mean baseline $\mathrm{pH}$ after consumption of candies was increased in group II at 10 to 30 minutes, with the highest value at 30 minutes. Even though a slight drop in $\mathrm{pH}$ was noted after 20 minutes of consumption of paneer, all values stayed more elevated than the levels seen after consumption of candies, significantly $(p<0.001)$. The final value achieved at the end of 30 minutes after paneer consumption was higher than the baseline $\mathrm{pH}$ values and was statistically significant ( $p=0.004 ;-$ Table 2 ; - Fig. 1 ).

Intergroup comparison of the changes in salivary $\mathrm{pH}$ from baseline after rinsing with water and paneer consumption have shown that increase in the $\mathrm{pH}$ value seen after

Table 1 Salivary $\mathrm{pH}$ at baseline, after the consumption of candies and after rinsing with water

\begin{tabular}{|c|c|c|c|c|c|c|c|c|}
\hline \multirow[b]{2}{*}{ Sr. no. } & \multicolumn{4}{|l|}{ Paired samples statistics } & \multicolumn{2}{|c|}{ Paired differences } & \multirow[t]{2}{*}{$t$} & \multirow[t]{2}{*}{$p$-Value } \\
\hline & $\begin{array}{l}\text { Parameter } \\
\text { (salivary pH) }\end{array}$ & Mean & $n$ & $\begin{array}{l}\text { Standard } \\
\text { deviation }\end{array}$ & Mean & $\begin{array}{l}\text { Standard } \\
\text { deviation }\end{array}$ & & \\
\hline \multirow[t]{2}{*}{1} & Baseline & 7.043333 & 30 & 0.3136914 & 0.883333 & 0.296047 & 16.343 & $<0.001^{\mathrm{a}}$ \\
\hline & 10 minutes after candies & 6.160000 & 30 & 0.3420022 & & & & \\
\hline \multirow[t]{2}{*}{2} & 10 minutes after candies & 6.160000 & 30 & 0.3420022 & -0.31667 & 0.258755 & -6.703 & $<0.001^{\mathrm{a}}$ \\
\hline & 10 minutes after water & 6.476667 & 30 & 0.3757139 & & & & \\
\hline \multirow[t]{2}{*}{3} & 10 minutes after candies & 6.160000 & 30 & 0.3420022 & -0.52667 & 0.3237 & -8.912 & $<0.001^{\mathrm{a}}$ \\
\hline & 20 minutes after water & 6.686667 & 30 & 0.3785028 & & & & \\
\hline \multirow[t]{2}{*}{4} & 10 minutes after candies & 6.160000 & 30 & 0.3420022 & -0.73333 & 0.272072 & -14.763 & $<0.001^{\mathrm{a}}$ \\
\hline & 30 minutes after water & 6.89333333 & 30 & 0.297035158 & & & & \\
\hline \multirow[t]{2}{*}{5} & 10 minutes after water & 6.476667 & 30 & 0.3757139 & -0.21 & 0.22796 & -5.046 & $<0.001^{\mathrm{a}}$ \\
\hline & 20 minutes after water & 6.686667 & 30 & 0.3785028 & & & & \\
\hline \multirow[t]{2}{*}{6} & 10 minutes after water & 6.476667 & 30 & 0.3757139 & -0.41667 & 0.226035 & -10.097 & $<0.001^{\mathrm{a}}$ \\
\hline & 30 minutes after water & 6.89333333 & 30 & 0.297035158 & & & & \\
\hline \multirow[t]{2}{*}{7} & 20 minutes after water & 6.686667 & 30 & 0.3785028 & -0.20667 & 0.214851 & -5.269 & $<0.001^{\mathrm{a}}$ \\
\hline & 30 minutes after water & 6.89333333 & 30 & 0.297035158 & & & & \\
\hline \multirow[t]{2}{*}{8} & Baseline & 7.043333 & 30 & 0.3136914 & 0.15 & 0.171705 & 4.785 & $<0.001^{\mathrm{a}}$ \\
\hline & 30 minutes after water & 6.89333333 & 30 & 0.297035158 & & & & \\
\hline
\end{tabular}

${ }^{a} p<0.001$ : very highly significant. 
Table 2 Salivary $\mathrm{pH}$ at baseline, after the consumption of candies and after the consumption of paneer $(20 \mathrm{~g})$

\begin{tabular}{|c|c|c|c|c|c|c|c|c|}
\hline \multirow[b]{2}{*}{ Sr. no. } & \multicolumn{4}{|l|}{ Paired samples statistics } & \multicolumn{2}{|c|}{ Paired differences } & \multirow[t]{2}{*}{$t$} & \multirow[t]{2}{*}{$p$-Value } \\
\hline & $\begin{array}{l}\text { Parameter } \\
\text { (salivary pH) }\end{array}$ & Mean & $n$ & $\begin{array}{l}\text { Standard } \\
\text { deviation }\end{array}$ & Mean & $\begin{array}{l}\text { Standard } \\
\text { deviation }\end{array}$ & & \\
\hline \multirow[t]{2}{*}{1} & Baseline & 7.023333 & 30 & 0.5015035 & 0.676667 & 0.507654 & 7.301 & $<0.001^{\mathrm{c}}$ \\
\hline & 10 minutes after candies & 6.346667 & 30 & 0.4761435 & & & & \\
\hline \multirow[t]{2}{*}{2} & 10 minutes after candies & 6.346667 & 30 & 0.4761435 & -0.76333 & 0.567805 & -7.363 & $<0.001^{\mathrm{c}}$ \\
\hline & 10 minutes after paneer & 7.110000 & 30 & 0.5862505 & & & & \\
\hline \multirow[t]{2}{*}{3} & 10 minutes after candies & 6.346667 & 30 & 0.4761435 & -0.73 & 0.463978 & -8.618 & $<0.001^{\mathrm{c}}$ \\
\hline & 20 minutes after paneer & 7.076667 & 30 & 0.4264394 & & & & \\
\hline \multirow[t]{2}{*}{4} & 10 minutes after candies & 6.346667 & 30 & 0.4761435 & -0.91333 & 0.459185 & -10.894 & $<0.001^{\mathrm{c}}$ \\
\hline & 30 minute after paneer & 7.26000000 & 30 & 0.402235135 & & & & \\
\hline \multirow[t]{2}{*}{5} & 10 minute after paneer & 7.110000 & 30 & 0.5862505 & 0.033333 & 0.392458 & 0.465 & $0.645^{\mathrm{a}}$ \\
\hline & 20 minutes after paneer & 7.076667 & 30 & 0.4264394 & & & & \\
\hline \multirow[t]{2}{*}{6} & 10 minutes after paneer & 7.110000 & 30 & 0.5862505 & -0.15 & 0.462191 & -1.778 & $0.086^{\mathrm{a}}$ \\
\hline & 30 minutes after paneer & 7.26000000 & 30 & 0.402235135 & & & & \\
\hline \multirow[t]{2}{*}{7} & 20 minutes after paneer & 7.076667 & 30 & 0.4264394 & -0.18333 & 0.304091 & -3.302 & $0.003^{b}$ \\
\hline & 30 minutes after paneer & 7.26000000 & 30 & 0.402235135 & & & & \\
\hline \multirow[t]{2}{*}{8} & Baseline & 7.023333 & 30 & 0.5015035 & -0.23667 & 0.40978 & -3.163 & $0.004^{\mathrm{b}}$ \\
\hline & 30 minutes after paneer & 7.26000000 & 30 & 0.402235135 & & & & \\
\hline
\end{tabular}

${ }^{a} p>0.05$ : not significant.

${ }^{\mathrm{b}} p<0.05$ : significant.

${ }^{c} p<0.001$ : very highly significant

Table 3 Intergroup comparison of changes in salivary $\mathrm{pH}$ from baseline after rinsing with water and consumption of paneer: post hoc Tukey's test

\begin{tabular}{|c|c|c|c|c|c|c|}
\hline \multicolumn{2}{|c|}{ Parameter } & \multirow{2}{*}{$\begin{array}{l}\text { I group } \\
\text { Water }\end{array}$} & \multirow{2}{*}{$\begin{array}{l}\text { J group } \\
\text { Paneer }\end{array}$} & \multirow{2}{*}{$\begin{array}{l}\begin{array}{l}\text { Mean } \\
\text { difference }(I-J)\end{array} \\
-0.39\end{array}$} & \multirow{2}{*}{$\begin{array}{l}\begin{array}{l}\text { Standard } \\
\text { error }\end{array} \\
0.09\end{array}$} & \multirow{2}{*}{$\begin{array}{l}p \text {-Value } \\
5.5 \mathrm{E}-05\end{array}$} \\
\hline $\mathrm{pH}$ & Difference 30 minutes after test sample to baseline & & & & & \\
\hline & $\begin{array}{l}\text { Difference } 10 \text { minutes after test sample to } \\
10 \text { minute after candy }\end{array}$ & Water & Paneer & -0.45 & 0.11 & 0.000386 \\
\hline & $\begin{array}{l}\text { Difference } 20 \text { minutes after test sample to } \\
10 \text { minute after candy }\end{array}$ & Water & Paneer & -0.20 & 0.11 & 0.182512 \\
\hline & $\begin{array}{l}\text { Difference } 30 \text { minutes after test sample to } \\
10 \text { minute after candy }\end{array}$ & Water & Paneer & -0.18 & 0.10 & 0.186158 \\
\hline
\end{tabular}

Note: $\mathrm{E}=10^{\mathrm{x}}$

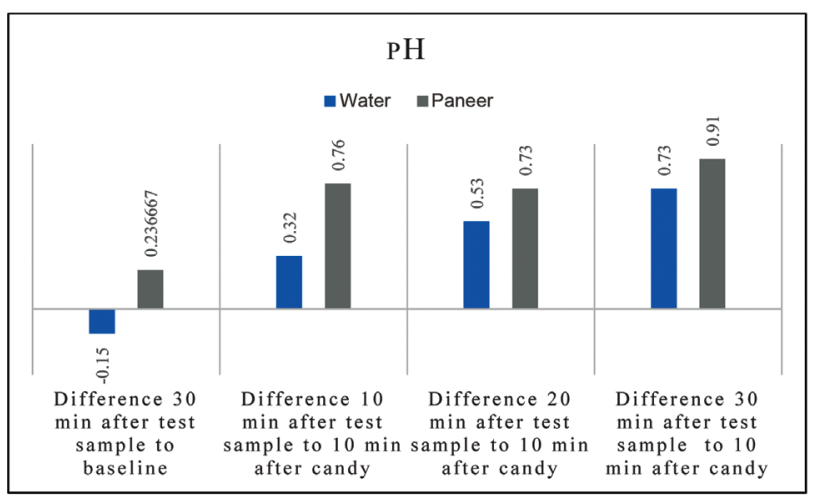

Fig. 2 Intergroup comparison of changes in salivary $\mathrm{pH}$ from baseline after rinsing with water and consumption of paneer.
10 minutes of paneer consumption was significantly higher than water. The comparison between the changes in $\mathrm{pH}$ in water and paneer has shown that the $\mathrm{pH}$ in the paneer group achieved after 30 minutes was significantly higher than the baseline compared with the water group (-Table 3; - Fig. 2 ).

\section{Calcium}

A decline in the mean calcium values from baseline after the consumption of candies was highly significant $(p<0.001)$. The calcium values increased after rinsing with water from 10,20 , to 30 minutes, and the difference was highly significant $(p<0.001)$. After 30 minutes of rinsing with water, the level was slightly above the baseline, and the difference was not significant. (-Table 4 ; - Fig. 3 ). 
Table 4 Calcium level in saliva at baseline, after the consumption of candies and after rinsing with water

\begin{tabular}{|c|c|c|c|c|c|c|c|c|}
\hline \multirow[b]{2}{*}{ Sr. no. } & \multicolumn{4}{|l|}{ Paired samples statistics } & \multicolumn{2}{|c|}{ Paired differences } & \multirow[t]{2}{*}{$t$} & \multirow[t]{2}{*}{$p$-Value } \\
\hline & $\begin{array}{l}\text { Parameter } \\
\text { (salivary calcium) }\end{array}$ & $\begin{array}{l}\text { Mean } \\
(\mathrm{mg} / \mathrm{dL})\end{array}$ & $n$ & $\begin{array}{l}\text { Standard } \\
\text { deviation }\end{array}$ & $\begin{array}{l}\text { Mean } \\
\text { (mg/dL) }\end{array}$ & $\begin{array}{l}\text { Standard } \\
\text { deviation }\end{array}$ & & \\
\hline \multirow[t]{2}{*}{1} & Baseline & 9.807017 & 30 & 1.1327041 & 2.211558 & 0.980069 & 12.36 & $<0.001^{c}$ \\
\hline & 10 minutes after candies & 7.595459 & 30 & 1.1860537 & & & & \\
\hline \multirow[t]{2}{*}{2} & 10 minutes after candies & 7.595459 & 30 & 1.1860537 & -1.25681 & 0.834719 & -8.247 & $<0.001^{c}$ \\
\hline & 10 minutes after water & 8.852269 & 30 & 1.3128995 & & & & \\
\hline \multirow[t]{2}{*}{3} & 10 minutes after candies & 7.595459 & 30 & 1.1860537 & -1.74994 & 0.968391 & -9.898 & $<0.001^{\mathrm{c}}$ \\
\hline & 20 minutes after water & 9.345394 & 30 & 1.0713825 & & & & \\
\hline \multirow[t]{2}{*}{4} & 10 minutes after candies & 7.595459 & 30 & 1.1860537 & -2.39747 & 0.926998 & -14.166 & $<0.001^{\mathrm{c}}$ \\
\hline & 30 minutes after water & 9.99292667 & 30 & 1.1206955 & & & & \\
\hline \multirow[t]{2}{*}{5} & 10 minutes after water & 8.852269 & 30 & 1.3128995 & -0.49313 & 0.920182 & -2.935 & $0.006^{\mathrm{b}}$ \\
\hline & 20 minutes after water & 9.345394 & 30 & 1.0713825 & & & & \\
\hline \multirow[t]{2}{*}{6} & 10 minutes after water & 8.852269 & 30 & 1.3128995 & -1.14066 & 0.901694 & -6.929 & $<0.001^{\mathrm{c}}$ \\
\hline & 30 minutes after water & 9.99292667 & 30 & 1.1206955 & & & & \\
\hline \multirow[t]{2}{*}{7} & 20 minutes after water & 9.345394 & 30 & 1.0713825 & -0.64753 & 0.680506 & -5.212 & $<0.001^{\mathrm{c}}$ \\
\hline & 30 minutes after water & 9.99292667 & 30 & 1.1206955 & & & & \\
\hline \multirow[t]{2}{*}{8} & Baseline & 9.807017 & 30 & 1.1327041 & -0.18591 & 0.665972 & -1.529 & $0.137^{\mathrm{a}}$ \\
\hline & 30 minutes after water & 9.99292667 & 30 & 1.1206955 & & & & \\
\hline
\end{tabular}

${ }^{a} p>0.05$ : not significant.

${ }^{\mathrm{b}} p<0.05$ : significant.

${ }^{c} p<0.001$ : very highly significant.

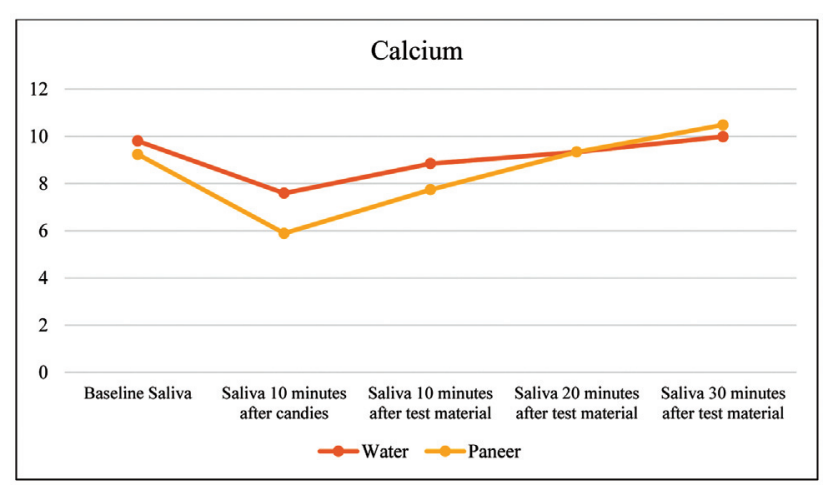

Fig. 3 Changes in the salivary calcium levels from baseline, after consumption of candies followed by water and paneer at different time intervals.

The mean baseline drop in the calcium level 10 minutes after the consumption of candies was increased after the intake of $20 \mathrm{~g}$ of paneer after 10,20 , and 30 minutes, significantly, and reached the highest value after 30 minutes. This increase was higher than baseline values and those seen after consuming candies and was statistically highly significant $(p<0.001$; - Table 5; - Fig. 3 ).

Intergroup comparison of changes in salivary calcium from baseline after rinsing with water and after the consumption of paneer that has shown a rise in calcium level after 10,20, and 30 minutes of test sample was higher for the paneer group as compared with water group, and the difference was statistically significant. The difference in the mean calcium values after 30 minutes of paneer from baseline was significantly higher compared with the water group (-Table 6; -Fig. 4).

\section{Phosphorus}

The baseline phosphorus value decreased after consumption of candies significantly ( $p<0.001$ and increased after rinsing with water from 10 minutes, with the highest value seen after 20 minutes significantly $(p<0.001)$. Though the final value at 30 minutes after rinsing with water was markedly higher than that seen after candies $(p<0.001)$, it was lesser than the baseline value with the significance of $p=0.043$ (-Table 7; -Fig. 5).

The drop in mean baseline phosphorus levels in saliva after the consumption of candies was significantly increased $(p<0.001) 10$ minutes after the consumption of paneer. The phosphorus value declined gradually after 20 and 30 minutes of consumption of paneer but remained above the baseline value. The difference between phosphorus level at baseline and 30 minutes after chewing paneer was highly, statistically significant ( $p<0.001$; - Table 8; - Fig. 5 ).

Intergroup comparison of changes in salivary phosphorus from baseline after rinsing with water and consumption of paneer has shown a higher rise in the phosphorus values in paneer group compared with the water 10 minutes after the consumption of paneer, and the difference was statistically significant. Paneer and water groups showed similar phosphorus values after 20 and 30 minutes. The difference between the values achieved after 30 minutes from the 
432 TAC of Saliva after the Consumption of Candies and Paneer Shah et al.

Table 5 Calcium level in saliva at baseline, after the consumption of candies and after the consumption of paneer ( $20 \mathrm{~g}$ )

\begin{tabular}{|c|c|c|c|c|c|c|c|c|}
\hline \multirow[b]{2}{*}{ Sr. no. } & \multicolumn{4}{|l|}{ Paired samples statistics } & \multicolumn{2}{|c|}{ Paired differences } & \multirow[t]{2}{*}{$t$} & \multirow[t]{2}{*}{$p$-Value } \\
\hline & $\begin{array}{l}\text { Parameter } \\
\text { (salivary calcium) }\end{array}$ & $\begin{array}{l}\text { Mean } \\
(\mathrm{mg} / \mathrm{dL})\end{array}$ & $n$ & $\begin{array}{l}\text { Standard } \\
\text { deviation }\end{array}$ & $\begin{array}{l}\text { Mean } \\
(\mathrm{mg} / \mathrm{dL})\end{array}$ & $\begin{array}{l}\text { Standard } \\
\text { deviation }\end{array}$ & & \\
\hline \multirow[t]{2}{*}{1} & Baseline & 9.239000 & 30 & 1.1092023 & 3.347367 & 1.689329 & 10.853 & $<0.001^{\mathrm{b}}$ \\
\hline & 10 minutes after candies & 5.891633 & 30 & 1.5165071 & & & & \\
\hline \multirow[t]{2}{*}{2} & 10 minutes after candies & 5.891633 & 30 & 1.5165071 & -1.85209 & 1.978874 & -5.126 & $<0.001^{\mathrm{b}}$ \\
\hline & 10 minutes after paneer & 7.743727 & 30 & 1.7982893 & & & & \\
\hline \multirow[t]{2}{*}{3} & 10 minutes after candies & 5.891633 & 30 & 1.5165071 & -3.45177 & 2.188084 & -8.64 & $<0.001^{b}$ \\
\hline & 20 minutes after paneer & 9.343400 & 30 & 1.6985676 & & & & \\
\hline \multirow[t]{2}{*}{4} & 10 minutes after candies & 5.891633 & 30 & 1.5165071 & -4.59403 & 1.643682 & -15.309 & $<0.001^{\mathrm{b}}$ \\
\hline & 30 minutes after paneer & 10.48566667 & 30 & 1.321948284 & & & & \\
\hline \multirow[t]{2}{*}{5} & 10 minutes after paneer & 7.743727 & 30 & 1.7982893 & -1.59967 & 2.374102 & -3.691 & $0.001^{\mathrm{a}}$ \\
\hline & 20 minutes after paneer & 9.343400 & 30 & 1.6985676 & & & & \\
\hline \multirow[t]{2}{*}{6} & 10 minutes after paneer & 7.743727 & 30 & 1.7982893 & -2.74194 & 2.421186 & -6.203 & $<0.001^{\mathrm{b}}$ \\
\hline & 30 minutes after paneer & 10.48566667 & 30 & 1.321948284 & & & & \\
\hline \multirow[t]{2}{*}{7} & 20 minutes after paneer & 9.343400 & 30 & 1.6985676 & -1.14227 & 1.780574 & -3.514 & $0.001^{a}$ \\
\hline & 30 minutes after paneer & 10.48566667 & 30 & 1.321948284 & & & & \\
\hline \multirow[t]{2}{*}{8} & Baseline & 9.239000 & 30 & 1.1092023 & -1.24667 & 1.250632 & -5.46 & $<0.001^{b}$ \\
\hline & 30 minutes after paneer & 10.48566667 & 30 & 1.321948284 & & & & \\
\hline
\end{tabular}

${ }^{a} p<0.01$ : highly significant.

${ }^{\mathrm{b}} p<0.001$ : very highly significant.

Table 6 Intergroup comparison of changes in salivary calcium from baseline after rinsing with water and consumption of paneer (post hoc Tukey's test)

\begin{tabular}{|c|c|c|c|c|c|c|}
\hline \multicolumn{2}{|c|}{ Parameter } & \multirow{2}{*}{$\begin{array}{l}\text { I group } \\
\text { Water }\end{array}$} & \multirow{2}{*}{$\begin{array}{l}\text { J group } \\
\text { Paneer }\end{array}$} & \multirow{2}{*}{$\begin{array}{l}\begin{array}{l}\text { Mean } \\
\text { difference (I-J) }\end{array} \\
-1.06\end{array}$} & \multirow{2}{*}{$\begin{array}{l}\text { Standard } \\
\text { error }\end{array}$} & \multirow{2}{*}{$\begin{array}{c}p \text {-Value } \\
0.000238\end{array}$} \\
\hline Calcium & $\begin{array}{l}\text { Difference between } 30 \text { minutes after test } \\
\text { sample to baseline }\end{array}$ & & & & & \\
\hline & $\begin{array}{l}\text { Difference between } 10 \text { minutes after test sample } \\
\text { to } 10 \text { minute after candy }\end{array}$ & Water & Paneer & -0.60 & 0.37 & 0.245738 \\
\hline & $\begin{array}{l}\text { Difference between } 20 \text { minutes after test sample } \\
\text { to } 10 \text { minute after candy }\end{array}$ & Water & Paneer & -1.70 & 0.41 & 0.000212 \\
\hline & $\begin{array}{l}\text { Difference between } 30 \text { minutes after test sample } \\
\text { to } 10 \text { minute after candy }\end{array}$ & Water & Paneer & -2.20 & 0.35 & 4.03E-08 \\
\hline
\end{tabular}

Note: $\mathrm{E}=10^{\mathrm{x}}$.

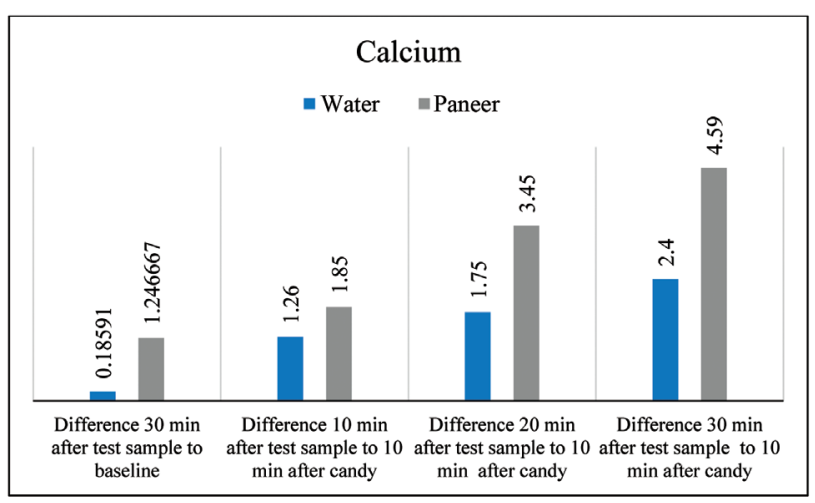

Fig. 4 Intergroup comparison of changes in salivary calcium from baseline after rinsing with water and consumption of paneer. baseline of the test sample was significantly higher in the paneer than in the water group (-Table 9; -Fig. 6).

\section{Alkaline Phosphatase}

The mean baseline alkaline phosphatase level decreased after intake of candies which was highly significant $(p<0.001)$. This value increased after rinsing with water at $10(p=0.001), 20$, and 30 minutes $(p<0.001)$ significantly. The highest value noted was 30 minutes after rinsing with water and was similar to baseline (-Table 10; - Fig. 7).

Reduction in the mean alkaline phosphatase level of saliva after consuming candies showed a gradual increase after chewing paneer from 10 to 30 minutes, and the increase was statistically significant $(p<0.001)$. The highest value noted 
Table 7 Phosphorus level in saliva at baseline, after the consumption of candies and after rinsing with water

\begin{tabular}{|c|c|c|c|c|c|c|c|c|}
\hline \multirow[b]{2}{*}{ Sr. no. } & \multicolumn{4}{|l|}{ Paired samples statistics } & \multicolumn{2}{|c|}{ Paired differences } & \multirow[t]{2}{*}{$t$} & \multirow[t]{2}{*}{$p$-Value } \\
\hline & $\begin{array}{l}\text { Parameter } \\
\text { (salivary phosphorus) }\end{array}$ & $\begin{array}{l}\text { Mean } \\
(\mathrm{mM} / \mathrm{L})\end{array}$ & $n$ & $\begin{array}{l}\text { standard } \\
\text { deviation }\end{array}$ & $\begin{array}{l}\text { Mean } \\
(\mathrm{mM} / \mathrm{L})\end{array}$ & $\begin{array}{l}\text { Standard } \\
\text { deviation }\end{array}$ & & \\
\hline \multirow[t]{2}{*}{1} & Baseline & 3.022735 & 30 & 1.1883085 & 1.64359 & 0.866504 & 10.389 & $<0.001^{c}$ \\
\hline & 10 minutes after candies & 1.379146 & 30 & 0.8992194 & & & & \\
\hline \multirow[t]{2}{*}{2} & 10 minutes after candies & 1.379146 & 30 & 0.8992194 & -1.33733 & 1.167673 & -6.273 & $<0.001^{c}$ \\
\hline & 10 minutes after water & 2.716473 & 30 & 1.5984194 & & & & \\
\hline \multirow[t]{2}{*}{3} & 10 minutes after candies & 1.379146 & 30 & 0.8992194 & -1.58625 & 0.947314 & -9.171 & $<0.001^{c}$ \\
\hline & 20 minutes after water & 2.965391 & 30 & 1.2216327 & & & & \\
\hline \multirow[t]{2}{*}{4} & 10 minutes after candies & 1.379146 & 30 & 0.8992194 & -1.47992 & 0.799888 & -10.134 & $<0.001^{\mathrm{c}}$ \\
\hline & 30 minutes after water & 2.85906100 & 30 & 1.118400332 & & & & \\
\hline \multirow[t]{2}{*}{5} & 10 minutes after water & 2.716473 & 30 & 1.5984194 & -0.24892 & 0.930019 & -1.466 & $0.153^{\mathrm{a}}$ \\
\hline & 20 minutes after water & 2.965391 & 30 & 1.2216327 & & & & \\
\hline \multirow[t]{2}{*}{6} & 10 minutes after water & 2.716473 & 30 & 1.5984194 & -0.14259 & 1.223582 & -0.638 & $0.528^{\mathrm{a}}$ \\
\hline & 30 minutes after water & 2.85906100 & 30 & 1.118400332 & & & & \\
\hline \multirow[t]{2}{*}{7} & 20 minutes after water & 2.965391 & 30 & 1.2216327 & 0.10633 & 0.81816 & 0.712 & $0.482^{\mathrm{a}}$ \\
\hline & 30 minutes after water & 2.85906100 & 30 & 1.118400332 & & & & \\
\hline \multirow[t]{2}{*}{8} & Baseline & 3.022735 & 30 & 1.1883085 & 0.163674 & 0.423943 & 2.115 & $0.043^{b}$ \\
\hline & 30 minutes after water & 2.85906100 & 30 & 1.118400332 & & & & \\
\hline
\end{tabular}

${ }^{a} p>0.05$ : not significant.

${ }^{\mathrm{b}} p<0.05$ : significant.

${ }^{c} p<0.001$ : very highly significant.

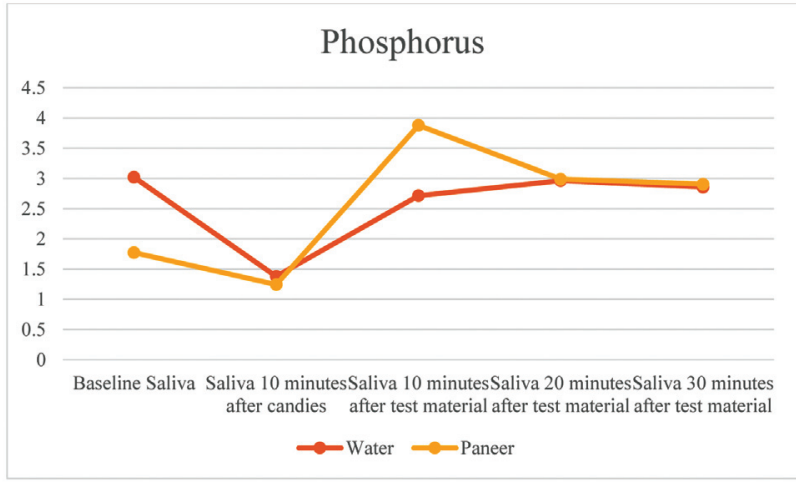

Fig. 5 Changes in the salivary phosphorus levels from baseline, after consumption of candies followed by water and paneer at different time intervals.

was at 30 minutes after chewing paneer, and it was significantly higher than the baseline ( $p<0.001$; - Table 11; - Fig. 7 ).

Salivary alkaline phosphatase from baseline after rinsing with water and 10 minutes after the consumption of paneer showed a significant increase in the values after candies which were comparable to water group. The rise in alkaline phosphatase seen after 20 and 30 minutes of consumption of the test material was similar in both groups. The difference between baseline level and after 30 minutes of the test material was significantly higher for the paneer group than the water group. The difference between the values achieved after 30 minutes from baseline of test sample was significantly higher in paneer group than the water group (-Table12; - Fig. 8).

\section{Total Antioxidant Capacity}

There was an increase in the TAC from the baseline value 10 minutes after consuming candies and was statistically significant $(p<0.001)$. This value decreased after rinsing with water significantly at $10(p=0.003), 20(p=0.001)$, and 30 minutes $(p<0.001)$, with the most negligible value noted after 30 minutes. The final value achieved 30 minutes after rinsing with water was similar to the baseline value (-Table 13; - Fig. 9).

The increase in mean baseline TAC value after the consumption of candies was decreased gradually after consumption of paneer from 10 to 30 minutes; however, the final values observed after 30 minutes were still higher than baseline, and these differences were statistically not significant (-Table 14; - Fig. 9).

The difference in TAC values after consuming candies and 10,20 , and 30 minutes of test materials were significantly higher in the paneer group than the water group. The difference between the TAC of saliva at baseline and 30 minutes after consumption of test material was higher for the paneer group than water, but the difference was not statistically significant (-Table 15; - Fig. 10).

\section{Discussion}

Key factors in determining dietary cariogenic, cariostatic, and anticariogenic properties are the food form and texture, frequency of fermentable carbohydrate consumption, retention time, nutrient composition, and the potential of the food 
434 TAC of Saliva after the Consumption of Candies and Paneer Shah et al.

Table 8 Phosphorus level in saliva at baseline, after the consumption of candies and after the consumption of paneer (20 g)

\begin{tabular}{|c|c|c|c|c|c|c|c|c|}
\hline \multirow[b]{2}{*}{ Sr. no. } & \multicolumn{4}{|l|}{ Paired samples statistics } & \multicolumn{2}{|c|}{ Paired differences } & \multirow[t]{2}{*}{$t$} & \multirow[t]{2}{*}{$p$-Value } \\
\hline & $\begin{array}{l}\text { Parameter } \\
\text { (salivary phosphorus) }\end{array}$ & $\begin{array}{l}\text { Mean } \\
(\mathrm{mM} / \mathrm{L})\end{array}$ & $n$ & $\begin{array}{l}\text { Standard } \\
\text { deviation }\end{array}$ & $\begin{array}{l}\text { Mean } \\
(\mathrm{mM} / \mathrm{L})\end{array}$ & $\begin{array}{l}\text { Standard } \\
\text { deviation }\end{array}$ & & \\
\hline \multirow[t]{2}{*}{1} & Baseline & 1.773733 & 30 & 0.4533707 & 0.528297 & 0.765219 & 3.781 & $0.001^{c}$ \\
\hline & 10 minutes after candies & 1.245437 & 30 & 0.7030305 & & & & \\
\hline \multirow[t]{2}{*}{2} & 10 minutes after candies & 1.245437 & 30 & 0.7030305 & -2.63403 & 1.28481 & -11.229 & $<0.001^{\mathrm{d}}$ \\
\hline & 10 minutes after paneer & 3.879467 & 30 & 1.4379901 & & & & \\
\hline \multirow[t]{2}{*}{3} & 10 minutes after candies & 1.245437 & 30 & 0.7030305 & -1.74426 & 1.431895 & -6.672 & $<0.001^{\mathrm{d}}$ \\
\hline & 20 minutes after paneer & 2.989700 & 30 & 1.0576180 & & & & \\
\hline \multirow[t]{2}{*}{4} & 10 minutes after candies & 1.245437 & 30 & 0.7030305 & -1.66127 & 1.067084 & -8.527 & $<0.001^{d}$ \\
\hline & 30 minutes after paneer & 2.90671000 & 30 & 0.807100946 & & & & \\
\hline \multirow[t]{2}{*}{5} & 10 minutes after paneer & 3.879467 & 30 & 1.4379901 & 0.889767 & 1.84942 & 2.635 & $0.013^{b}$ \\
\hline & 20 minutes after paneer & 2.989700 & 30 & 1.0576180 & & & & \\
\hline \multirow[t]{2}{*}{6} & 10 minutes after paneer & 3.879467 & 30 & 1.4379901 & 0.972757 & 1.616166 & 3.297 & $0.003^{b}$ \\
\hline & 30 minutes after paneer & 2.90671000 & 30 & 0.807100946 & & & & \\
\hline \multirow[t]{2}{*}{7} & 20 minutes after paneer & 2.989700 & 30 & 1.0576180 & 0.08299 & 1.198061 & 0.379 & $0.707^{a}$ \\
\hline & 30 minutes after paneer & 2.90671000 & 30 & 0.807100946 & & & & \\
\hline \multirow[t]{2}{*}{8} & Baseline & 1.773733 & 30 & 0.4533707 & -1.13298 & 0.983994 & -6.307 & $<0.001^{\mathrm{d}}$ \\
\hline & 30 minutes after paneer & 2.90671000 & 30 & 0.807100946 & & & & \\
\hline
\end{tabular}

${ }^{a} p>0.05$ : not significant.

${ }^{\mathrm{b}} p<0.05$ : significant.

${ }^{c} p<0.01$ : highly significant.

${ }^{d} p<0.001$ : very highly significant.

Table 9 Intergroup comparison of changes in salivary phosphorus from baseline after rinsing with water and consumption of paneer (post hoc Tukey's test)

\begin{tabular}{|l|l|l|l|l|l|l|}
\hline Parameter & & I group & J group & $\begin{array}{l}\text { Mean } \\
\text { difference (I-J) }\end{array}$ & $\begin{array}{l}\text { Standard } \\
\text { error }\end{array}$ & \begin{tabular}{l}
$p$-Value \\
\hline Phosphorous
\end{tabular} \\
$\begin{array}{l}\text { Difference between } 30 \text { minutes after test sample } \\
\text { to baseline }\end{array}$ & Water & Paneer & -1.30 & 0.22 & $3.49 \mathrm{E}-07$ \\
\cline { 2 - 6 } & $\begin{array}{l}\text { Difference between } 10 \text { minutes after test sample } \\
\text { to } 10 \text { minutes after candy }\end{array}$ & Water & Paneer & -1.30 & 0.29 & $5.8 \mathrm{E}-05$ \\
\cline { 2 - 7 } & $\begin{array}{l}\text { Difference between } 20 \text { minutes after test sample } \\
\text { to } 10 \text { minutes after candy }\end{array}$ & Water & Paneer & -0.16 & 0.33 & 0.882632 \\
\cline { 2 - 6 } & $\begin{array}{l}\text { Difference between } 30 \text { minutes after test sample } \\
\text { to } 10 \text { minute after candy }\end{array}$ & Water & Paneer & -0.18 & 0.27 & 0.777574 \\
\hline
\end{tabular}

Note: $\mathrm{E}=10^{\mathrm{x}}$.

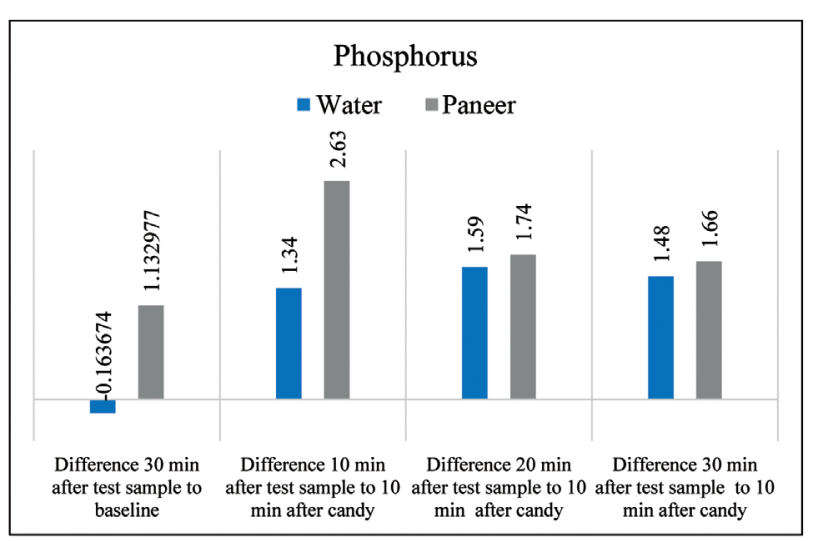

Fig. 6 Intergroup comparison of changes in salivary phosphorus from baseline after rinsing with water and consumption of paneer. to stimulate saliva and different combinations of food. The cariogenic potential of sweetened candies has already been established and hence we have chosen them as the demineralizing agent in this study.

Milk and dairy products form an essential part of the daily diet. They are not only natural but also act as precursors for various bioactive substances. They have also been recommended because they are a rich source of multiple proteins, potassium, vitamin D, lactoferrin, lysozyme, fats, and minerals like calcium and phosphorus. There is a considerable amount of data available on the protective effect of milk and milk products against dental caries. ${ }^{15-17}$

Research suggests that the beneficial role of milk and related products can be attributed to its high buffering capacity and other components like high calcium, 
Table 10 Alkaline phosphatase level in saliva at baseline, after the consumption of candies and after rinsing with water

\begin{tabular}{|c|c|c|c|c|c|c|c|c|}
\hline \multirow[b]{2}{*}{ Sr. no. } & \multicolumn{4}{|l|}{ Paired samples statistics } & \multicolumn{2}{|c|}{ Paired differences } & \multirow[t]{2}{*}{$t$} & \multirow[t]{2}{*}{$p$-Value } \\
\hline & $\begin{array}{l}\text { Parameter } \\
\text { (alkaline phosphatase) }\end{array}$ & $\begin{array}{l}\text { Mean } \\
\text { (U/L) }\end{array}$ & $n$ & $\begin{array}{l}\text { Standard } \\
\text { deviation }\end{array}$ & $\begin{array}{l}\text { Mean } \\
\text { (U/L) }\end{array}$ & $\begin{array}{l}\text { Standard } \\
\text { deviation }\end{array}$ & & \\
\hline \multirow[t]{2}{*}{1} & Baseline & 47.998133 & 30 & 35.3033127 & 21.71813 & 30.30231 & 3.926 & $<0.001^{\mathrm{c}}$ \\
\hline & 10 minutes after candies & 26.280000 & 30 & 16.9392607 & & & & \\
\hline \multirow[t]{2}{*}{2} & 10 minutes after candies & 26.280000 & 30 & 16.9392607 & -18.368 & 27.55319 & -3.651 & $0.001^{\mathrm{b}}$ \\
\hline & 10 minutes after water & 44.648000 & 30 & 32.8716269 & & & & \\
\hline \multirow[t]{2}{*}{3} & 10 minutes after candies & 26.280000 & 30 & 16.9392607 & -17.6657 & 21.31189 & -4.54 & $<0.001^{\mathrm{c}}$ \\
\hline & 20 minutes after water & 43.945667 & 30 & 24.1040071 & & & & \\
\hline \multirow[t]{2}{*}{4} & 10 minutes after candies & 26.280000 & 30 & 16.9392607 & -22.489 & 26.15324 & -4.71 & $<0.001^{\mathrm{c}}$ \\
\hline & 30 minutes after water & 48.76900000 & 30 & 25.606007559 & & & & \\
\hline \multirow[t]{2}{*}{5} & 10 minutes after water & 44.648000 & 30 & 32.8716269 & 0.702333 & 23.49903 & 0.164 & $0.871^{\mathrm{a}}$ \\
\hline & 20 minutes after water & 43.945667 & 30 & 24.1040071 & & & & \\
\hline \multirow[t]{2}{*}{6} & 10 minutes after water & 44.648000 & 30 & 32.8716269 & -4.121 & 31.31382 & -0.721 & $0.477^{\mathrm{a}}$ \\
\hline & 30 minutes after water & 48.76900000 & 30 & 25.606007559 & & & & \\
\hline \multirow[t]{2}{*}{7} & 20 minutes after water & 43.945667 & 30 & 24.1040071 & -4.82333 & 22.49303 & -1.175 & $0.25^{a}$ \\
\hline & 30 minutes after water & 48.76900000 & 30 & 25.606007559 & & & & \\
\hline \multirow[t]{2}{*}{8} & Baseline & 47.998133 & 30 & 35.3033127 & -0.77087 & 28.09139 & -0.15 & $0.882^{\mathrm{a}}$ \\
\hline & 30 minutes after water & 48.76900000 & 30 & 25.606007559 & & & & \\
\hline
\end{tabular}

${ }^{a} p>0.05$ : not significant.

${ }^{\mathrm{b}} \mathrm{p}<0.01$ : highly significant.

${ }^{c} p<0.001$ : very highly significant.

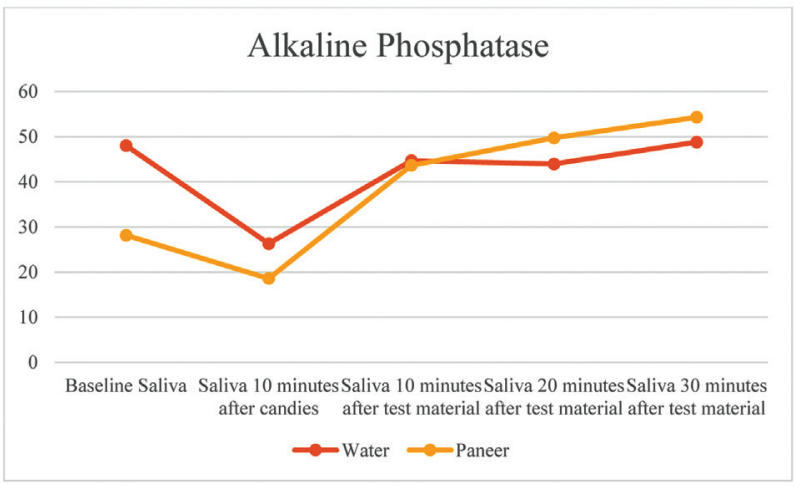

Fig 7 Changes in the salivary alkaline phosphatase levels from baseline, after consumption of candies followed by water and paneer at different time intervals.

phosphorus, lactoperoxidase, and casein. They have also been implicated to play a role in the prevention of bacterial attachment and biofilm formation by mechanical barrier formation or by inhibiting the bacterial glucosyltransferase enzyme. ${ }^{15,23}$ Lactoperoxidase and lysozyme in milk products inhibit the metabolism of Streptococcus mutans. ${ }^{15}$ Casein phosphopeptide (CPP), a fraction of casein present in dairy products, adsorbs to the enamel surface and impedes demineralization. It stabilizes amorphous calcium phosphate (ACP) which helps diffuse free calcium into the tooth. ${ }^{24}$

Commercially available remineralization technologies utilizing CPP-ACP complex have been proved as an adjunct to fluoride therapy in the remineralization of early carious lesions. ${ }^{25}$ We have used paneer in our study which is rich in casein, calcium, and phosphorus and has a similar mechanism of action. Paneer is natural, economical and can be homemade. It can be consumed by all age groups and patients with lactose intolerance without any health hazards. It has also been recommended for growing children due to the high content of various minerals, like calcium, phosphorus, magnesium, vitamin $\mathrm{D}$, and others, which helps in healthy teeth, as well as bone formation. ${ }^{26}$

The integrity of the oral cavity is maintained by saliva by mechanical cleansing. It aids oral clearance; has antioxidants to counteract oxidative stress; buffers the harmful effects of acids; provides ions, like iron, magnesium, phosphorus, calcium, fluoride, and others, for remineralization; and has various antibacterial properties. ${ }^{27}$ The delicate equilibrium of demineralization and remineralization to which the teeth are subjected to dwells on the $\mathrm{pH}$, calcium, phosphorus, alkaline phosphatase, and TAC of saliva. Thus in our study, we evaluated changes in these factors after a cariogenic challenge and its reversal with dairy products.

In our study, consumption of candies produced a cariogenic challenge and it was reflected as a sharp decline in the salivary $\mathrm{pH} 10$ minutes after the consumption of candies which is similar to the findings of Tayab et $\mathrm{al}^{22}$ and de Sousa et al. $^{28}$ This fall in $\mathrm{pH}$ is due to the production of organic acids, like lactic, acetic, propionic, butyric, and formic acids, by the plaque bacteria after the exposure to fermentable carbohydrates present in candies and is following Stephan's curve. 
Table 11 Alkaline phosphatase level in saliva at baseline, after the consumption of candies and after the consumption of paneer ( $20 \mathrm{~g}$ )

\begin{tabular}{|c|c|c|c|c|c|c|c|c|}
\hline \multirow[b]{2}{*}{ Sr. no. } & \multicolumn{4}{|l|}{ Paired samples statistics } & \multicolumn{2}{|c|}{ Paired differences } & \multirow[t]{2}{*}{$t$} & \multirow[t]{2}{*}{$p$-Value } \\
\hline & $\begin{array}{l}\text { Parameter } \\
\text { (alkaline phosphatase) }\end{array}$ & $\begin{array}{l}\text { Mean } \\
(\mathrm{U} / \mathrm{L})\end{array}$ & $n$ & $\begin{array}{l}\text { Standard } \\
\text { deviation }\end{array}$ & $\begin{array}{l}\text { Mean } \\
(U / L)\end{array}$ & $\begin{array}{l}\text { Standard } \\
\text { deviation }\end{array}$ & & \\
\hline \multirow[t]{2}{*}{1} & Baseline & 28.136333 & 30 & 11.7879253 & 9.585267 & 12.72702 & 4.125 & $<0.001^{\mathrm{c}}$ \\
\hline & 10 minutes after candies & 18.551067 & 30 & 10.1201537 & & & & \\
\hline \multirow[t]{2}{*}{2} & 10 minutes after candies & 18.551067 & 30 & 10.1201537 & -25.0596 & 27.74408 & -4.947 & $<0.001^{\mathrm{c}}$ \\
\hline & 10 minutes after paneer & 43.610667 & 30 & 29.7177747 & & & & \\
\hline \multirow[t]{2}{*}{3} & 10 minutes after candies & 18.551067 & 30 & 10.1201537 & -31.1643 & 34.50689 & -4.947 & $<0.001^{c}$ \\
\hline & 20 minutes after paneer & 49.715333 & 30 & 34.6158926 & & & & \\
\hline \multirow[t]{2}{*}{4} & 10 minutes after candies & 18.551067 & 30 & 10.1201537 & -35.7223 & 22.32262 & -8.765 & $<0.001^{\mathrm{c}}$ \\
\hline & 30 minutes after paneer & 54.2733333 & 30 & 19.78312662 & & & & \\
\hline \multirow[t]{2}{*}{5} & 10 minutes after paneer & 43.610667 & 30 & 29.7177747 & -6.10467 & 38.23993 & -0.874 & $0.389^{\mathrm{a}}$ \\
\hline & 20 minutes after paneer & 49.715333 & 30 & 34.6158926 & & & & \\
\hline \multirow[t]{2}{*}{6} & 10 minutes after paneer & 43.610667 & 30 & 29.7177747 & -10.6627 & 28.38821 & -2.057 & $0.049^{b}$ \\
\hline & 30 minutes after paneer & 54.2733333 & 30 & 19.78312662 & & & & \\
\hline \multirow[t]{2}{*}{7} & 20 minutes after paneer & 49.715333 & 30 & 34.6158926 & -4.558 & 38.41134 & -0.65 & $0.521^{\mathrm{a}}$ \\
\hline & 30 minutes after paneer & 54.2733333 & 30 & 19.78312662 & & & & \\
\hline \multirow[t]{2}{*}{8} & Baseline & 28.136333 & 30 & 11.7879253 & -26.137 & 22.22304 & -6.442 & $<0.001^{\mathrm{c}}$ \\
\hline & 30 minutes after paneer & 54.2733333 & 30 & 19.78312662 & & & & \\
\hline
\end{tabular}

${ }^{a} p>0.05$ : not significant.

${ }^{b} p<0.05$ : significant.

${ }^{c} p<0.001$ : very highly significant.

Table 12 Intergroup comparison of changes in salivary alkaline phosphatase from baseline after rinsing with water and consumption of paneer (post hoc Tukey's test)

\begin{tabular}{|c|c|c|c|c|c|c|}
\hline Parameter & & I group & J group & $\begin{array}{l}\text { Mean } \\
\text { difference (I-J) }\end{array}$ & $\begin{array}{l}\text { Standard } \\
\text { error }\end{array}$ & $p$-Value \\
\hline \multirow[t]{4}{*}{$\begin{array}{l}\text { Alkaline } \\
\text { phosphatase }\end{array}$} & $\begin{array}{l}\text { Difference between } 30 \mathrm{~s} \text { after test sample } \\
\text { to baseline }\end{array}$ & Water & Paneer & -25.37 & 6.35 & 0.000396 \\
\hline & $\begin{array}{l}\text { Difference between } 10 \text { minutes after test sample } \\
\text { to } 10 \text { minute after candy }\end{array}$ & Water & Paneer & -6.69 & 6.63 & 0.573397 \\
\hline & $\begin{array}{l}\text { Difference between } 20 \text { minutes after test sample } \\
\text { to } 10 \text { minute after candy }\end{array}$ & Water & Paneer & -13.50 & 9.77 & 0.354843 \\
\hline & $\begin{array}{l}\text { Difference between } 30 \text { minutes after test sample } \\
\text { to } 10 \text { minute after candy }\end{array}$ & Water & Paneer & -13.23 & 5.99 & 0.075505 \\
\hline
\end{tabular}

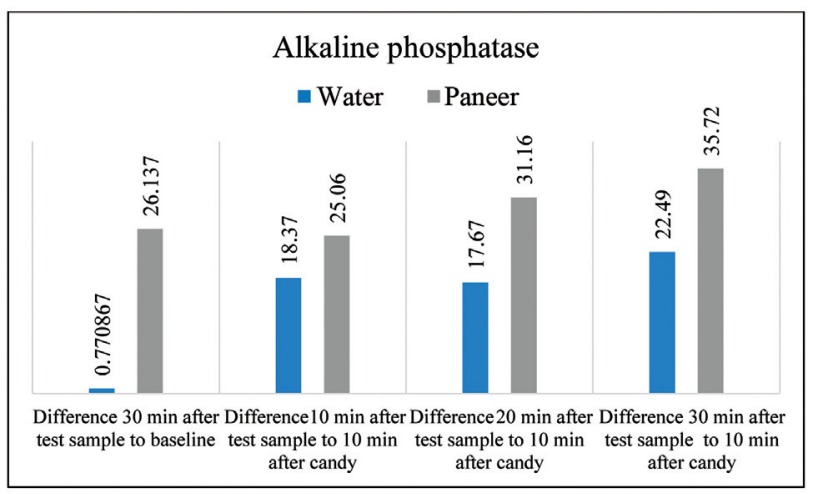

Fig. 8 Intergroup comparison of changes in salivary alkaline phosphatase from baseline after rinsing with water and consumption of paneer.
The rise in $\mathrm{pH}$ after rinsing with water can be attributed to the mechanical clearance of the cariogenic challenge and saliva stimulation. The significant rise in $\mathrm{pH}$ after consumption of paneer from 10 to 30 minutes was significantly higher than the baseline $\mathrm{pH}$. This observation was similar to that by Sharma et al, ${ }^{16}$ Sönmez and Aras, ${ }^{19}$ Tayab et al, ${ }^{22}$ Higham and Edgar, ${ }^{29}$ and Somaraj et $\mathrm{al}^{30}$ and who demonstrated a $\mathrm{pH}$ reversal when paneer was eaten after sugar exposure. This shows the prolonged anticariogenic effects of paneer by acting as sialogogues, increasing the buffering capacity of saliva, ${ }^{31}$ and enhancing the carbohydrate clearance due to their physical form and texture. Casein, lactoperoxidase, and lysozyme in milk products inhibit adherence and metabolism of $S$. mutans which further reduces the acids 
Table 13 TAC level in saliva at baseline, after the consumption of candies and after rinsing with water

\begin{tabular}{|c|c|c|c|c|c|c|c|c|}
\hline \multirow[b]{2}{*}{ Sr. no. } & \multicolumn{4}{|l|}{ Paired samples statistics } & \multicolumn{2}{|c|}{ Paired differences } & \multirow[t]{2}{*}{$t$} & \multirow[t]{2}{*}{$p$-Value } \\
\hline & Parameter (TAC) & $\begin{array}{l}\text { Mean } \\
(\mathrm{mM} / \mathrm{L})\end{array}$ & $n$ & $\begin{array}{l}\text { Standard } \\
\text { deviation }\end{array}$ & $\begin{array}{l}\text { Mean } \\
(\mathrm{mM} / \mathrm{L})\end{array}$ & $\begin{array}{l}\text { Standard } \\
\text { deviation }\end{array}$ & & \\
\hline \multirow[t]{2}{*}{1} & Baseline & 0.984111 & 30 & 0.4907979 & -0.96918 & 1.292882 & -4.106 & $<0.001^{\mathrm{d}}$ \\
\hline & 10 minutes after candies & 1.953290 & 30 & 1.1514248 & & & & \\
\hline \multirow[t]{2}{*}{2} & 10 minutes after candies & 1.953290 & 30 & 1.1514248 & 0.656449 & 1.120536 & 3.209 & $0.003^{b}$ \\
\hline & 10 minutes after water & 1.296842 & 30 & 0.4914402 & & & & \\
\hline \multirow[t]{2}{*}{3} & 10 minutes after candies & 1.953290 & 30 & 1.1514248 & 1.035572 & 1.452751 & 3.904 & $0.001^{c}$ \\
\hline & 20 minutes after water & 0.917718 & 30 & 0.4378874 & & & & \\
\hline \multirow[t]{2}{*}{4} & 10 minutes after candies & 1.953290 & 30 & 1.1514248 & 1.095358 & 1.295519 & 4.631 & $<0.001^{d}$ \\
\hline & 30 minutes after water & 0.85793244 & 30 & 0.359065346 & & & & \\
\hline \multirow[t]{2}{*}{5} & 10 minutes after water & 1.296842 & 30 & 0.4914402 & 0.379124 & 0.68005 & 3.054 & $0.005^{\mathrm{b}}$ \\
\hline & 20 minutes after water & 0.917718 & 30 & 0.4378874 & & & & \\
\hline \multirow[t]{2}{*}{6} & 10 minutes after water & 1.296842 & 30 & 0.4914402 & 0.438909 & 0.632879 & 3.799 & $0.001^{\mathrm{c}}$ \\
\hline & 30 minutes after water & 0.85793244 & 30 & 0.359065346 & & & & \\
\hline \multirow[t]{2}{*}{7} & 20 minutes after water & 0.917718 & 30 & 0.4378874 & 0.059786 & 0.596044 & 0.549 & $0.587^{\mathrm{a}}$ \\
\hline & 30 minutes after water & 0.85793244 & 30 & 0.359065346 & & & & \\
\hline \multirow[t]{2}{*}{8} & Baseline & 0.984111 & 30 & 0.4907979 & 0.126178 & 0.641432 & 1.077 & $0.29^{a}$ \\
\hline & 30 minutes after water & 0.85793244 & 30 & 0.359065346 & & & & \\
\hline
\end{tabular}

${ }^{a} p>0.05$ : not significant.

${ }^{\mathrm{b}} p<0.05$ : significant.

${ }^{c} p<0.01$ : highly significant.

${ }^{d} p<0.001$ : very highly significant.

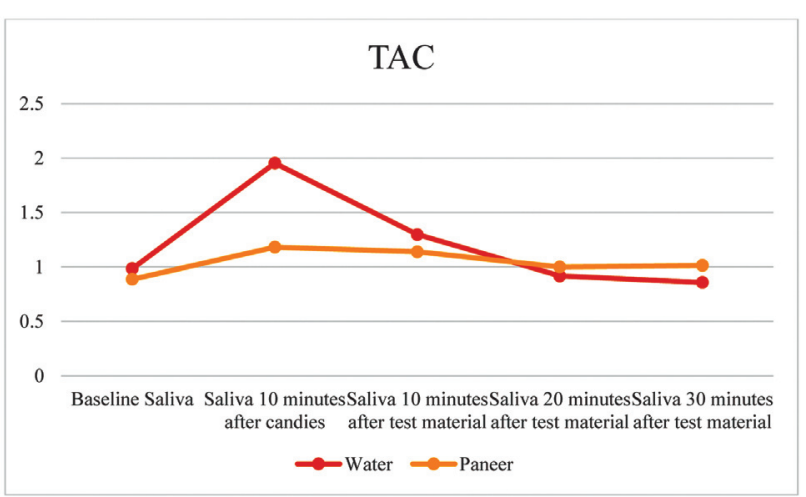

Fig. 9 Changes in the salivary TAC from baseline, after consumption of candies followed by water and paneer at different time intervals. TAC, total antioxidant capacity.

produced. ${ }^{32}$ CPP released by proteolysis of dairy products increases saliva saturation for calcium and phosphorus, increasing the $\mathrm{pH}$.

The significant drop in calcium and phosphorus levels in saliva 10 minutes after consuming candies demonstrate their ability to cause demineralization. These ions may be utilized from the saliva to maintain the ionic gradient. Also, lower calcium and phosphorus levels have been seen in previous studies in children with high caries incidence. ${ }^{8,33}$

After the cariogenic challenge, the consumption of paneer showed a significant rise in calcium and phosphorus values in our study after 10 minutes itself which could be due to the higher levels of calcium and phosphorus in paneer. This correlates with the study by Ravishankar et $\mathrm{al}^{32}$ and Moynihan et al. ${ }^{18}$ Kashket and DePaola stated that milk products increase the calcium and phosphorus level in plaque thus diminishing demineralization and favoring remineralization. ${ }^{34}$ Also, the casein present in milk products forms casein phosphopeptide on tryptic proteolysis. These form CPP-ACP complexes which stabilize colloidal calcium and phosphates, maintaining their supersaturation in saliva. These readily diffuse in plaque, favoring remineralization. Intergroup comparison showed consumption of paneer had significantly higher values of calcium and phosphorus than the water group at all times.

The alkaline phosphatase levels in both groups decreased after the intake of candies from baseline. However, our findings contradicted studies by Pandey et $\mathrm{al}^{35}$ and Gandhy and Damle ${ }^{36}$ where higher inorganic phosphorus and alkaline phosphatase levels were noted with increased caries whereas study by Vahedi et $\mathrm{al}^{37}$ showed no relation between dental caries and alkaline phosphatase.

The alkaline phosphatase values increased significantly from 10 to 30 minutes after rinsing with water, and the consumption of paneer with paneer groups showing significantly higher values. Demineralization and remineralization depend on minerals, like calcium and phosphorus, which are influenced by alkaline phosphatase levels. Since our findings contradict most of the studies, ${ }^{35,36}$ further research is needed to evaluate the changes in alkaline phosphatase levels of saliva following the cariogenic challenge and remineralization. 
Table 14 Total antioxidant capacity (TAC) level in saliva at baseline, after the consumption of candies and after the consumption of paneer $(20 \mathrm{~g})$

\begin{tabular}{|c|c|c|c|c|c|c|c|c|}
\hline \multirow[b]{2}{*}{ Sr. no. } & \multicolumn{4}{|l|}{ Paired samples statistics } & \multicolumn{2}{|c|}{ Paired differences } & \multirow[t]{2}{*}{$t$} & \multirow[t]{2}{*}{$p$-Value } \\
\hline & Parameter (TAC) & $\begin{array}{l}\text { Mean } \\
(\mathrm{mM} / \mathrm{L})\end{array}$ & $n$ & $\begin{array}{l}\text { Standard } \\
\text { deviation }\end{array}$ & $\begin{array}{l}\text { Mean } \\
(\mathrm{mM} / \mathrm{L})\end{array}$ & $\begin{array}{l}\text { Standard } \\
\text { deviation }\end{array}$ & & \\
\hline \multirow[t]{2}{*}{1} & Baseline & 0.887422 & 30 & 0.3971692 & -0.29355 & 0.668406 & -2.406 & $0.023^{b}$ \\
\hline & 10 minutes after candies & 1.180975 & 30 & 0.5293483 & & & & \\
\hline \multirow[t]{2}{*}{2} & 10 minutes after candies & 1.180975 & 30 & 0.5293483 & 0.042689 & 0.59254 & 0.395 & $0.696^{a}$ \\
\hline & 10 minutes after paneer & 1.138286 & 30 & 0.3472459 & & & & \\
\hline \multirow[t]{2}{*}{3} & 10 minutes after candies & 1.180975 & 30 & 0.5293483 & 0.181918 & 0.66374 & 1.501 & $0.144^{\mathrm{a}}$ \\
\hline & 20 minutes after paneer & 0.999057 & 30 & 0.3146654 & & & & \\
\hline \multirow[t]{2}{*}{4} & 10 minutes after candies & 1.180975 & 30 & 0.5293483 & 0.166824 & 0.609027 & 1.5 & $0.144^{\mathrm{a}}$ \\
\hline & 30 minutes after paneer & 1.01415090 & 30 & 0.322006250 & & & & \\
\hline \multirow[t]{2}{*}{5} & 10 minutes after paneer & 1.138286 & 30 & 0.3472459 & 0.13923 & 0.470108 & 1.622 & $0.116^{\mathrm{a}}$ \\
\hline & 20 minutes after paneer & 0.999057 & 30 & 0.3146654 & & & & \\
\hline \multirow[t]{2}{*}{6} & 10 minutes after paneer & 1.138286 & 30 & 0.3472459 & 0.124135 & 0.444355 & 1.53 & $0.137^{\mathrm{a}}$ \\
\hline & 30 minutes after paneer & 1.01415090 & 30 & 0.322006250 & & & & \\
\hline \multirow[t]{2}{*}{7} & 20 minutes after paneer & 0.999057 & 30 & 0.3146654 & -0.01509 & 0.464707 & -0.178 & $0.86^{\mathrm{a}}$ \\
\hline & 30 minutes after paneer & 1.01415090 & 30 & 0.322006250 & & & & \\
\hline \multirow[t]{2}{*}{8} & Baseline & 0.887422 & 30 & 0.3971692 & -0.12673 & 0.562472 & -1.234 & $0.227^{\mathrm{a}}$ \\
\hline & 30 minutes after paneer & 1.01415090 & 30 & 0.322006250 & & & & \\
\hline
\end{tabular}

${ }^{a} p>0.05$ : not significant.

${ }^{b} p<0.05$ : significant.

Table 15 Intergroup comparison of changes in salivary total antioxidant capacity (TAC) from baseline after rinsing with water and consumption of paneer (post hoc Tukey's test)

\begin{tabular}{|c|c|c|c|c|c|c|}
\hline \multicolumn{2}{|c|}{ Parameter } & \multirow{2}{*}{$\begin{array}{l}\text { I Group } \\
\text { Water }\end{array}$} & \multirow{2}{*}{$\begin{array}{l}\text { J Group } \\
\text { Paneer }\end{array}$} & \multirow{2}{*}{$\begin{array}{l}\begin{array}{l}\text { Mean } \\
\text { difference (I-J) }\end{array} \\
-0.25\end{array}$} & \multirow{2}{*}{$\begin{array}{l}\text { Standard } \\
\text { error }\end{array}$} & \multirow{2}{*}{$\begin{array}{l}p \text {-Value } \\
0.255943\end{array}$} \\
\hline TAC & Difference between 30 minute after test sample to baseline & & & & & \\
\hline & $\begin{array}{l}\text { Difference between } 10 \text { minute after test sample } \\
\text { to } 10 \text { minute after candy }\end{array}$ & Water & Paneer & -0.61 & 0.20 & 0.007934 \\
\hline & $\begin{array}{l}\text { Difference between } 20 \text { minute after test sample } \\
\text { to } 10 \text { minute after candy }\end{array}$ & Water & Paneer & -0.85 & 0.26 & 0.00384 \\
\hline & $\begin{array}{l}\text { Difference between } 30 \text { minute after test sample } \\
\text { to } 10 \text { minute after candy }\end{array}$ & Water & Paneer & -0.93 & 0.25 & 0.000944 \\
\hline
\end{tabular}

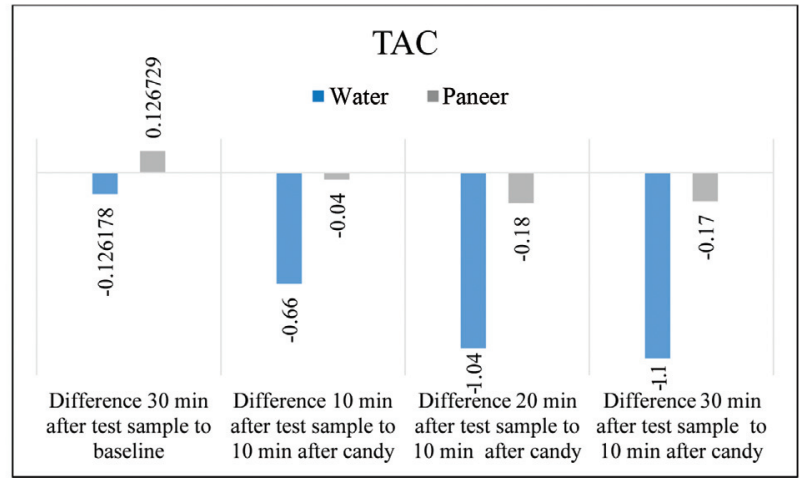

Fig. 10 Intergroup comparison of changes in salivary calcium from baseline after rinsing with water and consumption of paneer. TAC, total antioxidant capacity.
The salivary peroxidase system in one part determines the TAC of saliva. It catalyzes the peroxidation of thiocyanate to form hypothyocyanate which inhibits bacterial glycolysis. Many studies by Pandey et $\mathrm{al}^{33}$ and Mohammed et $\mathrm{al}^{38}$ have shown higher TAC in caries active children. But very few studies have been done on the antioxidants present in dairy products and their effect.

The TAC of saliva acts as a compensatory mechanism against the oxidative stresses produced by bacteria. Our study saw a rise in TAC from baseline after consuming candies, indicating increased bacterial activity.

The values decreased significantly after rinsing with water and consumption of paneer which showed a protective effect. These values were significantly lower than baseline at the end of 30 minutes after rinsing with water. 
They were higher than baseline after the consumption of paneer which could be attributed to the inherent antioxidants present in the dairy products. However, the intergroup comparison did not show much difference. Further studies must evaluate the antioxidants present in the dairy product and their role in the oral cavity after consumption.

\section{Conclusion}

Thus our study has proved that intake of sweetened candies creates a cariogenic environment conducive for demineralization. The efficacy of dairy products like paneer and consumption of water helps in the reversal of the cariogenic challenge caused by candies as evidenced in our findings.

\section{Conflict of Interest \\ None declared.}

\section{References}

1 Dental caries in the child and adolescent. In: Dean JA, Jones JE, Vinson LAW, eds. McDonald and Avery's Dentistry for the child and adolescent. 10th ed. St. Louis, MO: Elsevier; 2015:155-176

2 Luke GA, Gough H, Beeley JA, Geddes DA. Human salivary sugar clearance after sugar rinses and intake of foodstuffs. Caries Res 1999;33(02):123-129

3 Janakiram C, Antony B, Joseph J, Ramanarayanan V. Prevalence of dental caries in India among the WHO index age groups: a metaanalysis. J Clin Diagn Res 2018;12(08):ZE08-ZE13

4 Sarumathi T, Kumar S, Datta M, Hemalatha VT. Prevalence, severity and associated factors of dental caries in 3-6 year old children. J Clin Diagn Res 2013;7(08):1789-1792

5 Hegde AM, Shetty R, Sequeira AR. The acidogenicity of various chocolates available in the Indian market: a comparative study. Int J Clin Pediatr Dent 2009;2(02):20-24

6 Nirmala S, Quadar MA, Veluru S. pH modulation and salivary sugar clearance of different chocolates in children: a randomized clinical trial. J Indian Soc Pedod Prev Dent 2016;34(01): $10-16$

7 Morrissey RB, Burkholder BD, Tarka SM Jr. The cariogenic potential of several snack foods. J Am Dent Assoc 1984;109(04): 589-591

8 Aruna S, Meenakshi B, Rama KV, Valarmathi S. Salivary levels of calcium and phosphorus in children with and without early childhood caries: A pilot study. SRM J Res Dent Sci 2020; 11:72-75

9 Pyati SA, Naveen Kumar R, Kumar V, Praveen Kumar NH, Parveen Reddy KM. Salivary flow rate, $\mathrm{pH}$, buffering capacity, total protein, oxidative stress and antioxidant capacity in children with and without dental caries. J Clin Pediatr Dent 2018;42(06): 445-449

10 Sruthi KS, Yashoda R, Manjunath P. Diagnostic potential of saliva as a biomarker in early childhood caries: a review. Int J Appl Dent Sci 2019;5(02):341-347

11 Featherstone JD. The science and practice of caries prevention. J Am Dent Assoc 2000;131(07):887-899

12 Kim EE, Wyckoff HW. Reaction mechanism of alkaline phosphatase based on crystal structures. Two-metal ion catalysis. J Mol Biol 1991;218(02):449-464

13 Jain S, Bansal K, Marwaha M, Sehrawat N, Singla S. Effect of diet modification on salivary parameters and oratest in high-cariesrisk individuals. Int J Clin Pediatr Dent 2018;11(01):34-39

14 Woodward M, Rugg-Gunn AJ. Chapter 8: milk, yoghurts and dental caries. Monogr Oral Sci 2020;28:77-90
15 Johansson I. Milk and dairy products: possible effects on dental health. Scand J Nutr 2002;46(03):119-122

16 Sharma A, Sharma D, Singh S, Sharma A, Sharma R, Sharma M. Milk and its products: effect on salivary $\mathrm{pH}$. Int Healthcare Res J 2018;2(06):140-145

17 Mitoma M, Oho T, Shimazaki Y, Koga T. Inhibitory effect of bovine milk lactoferrin on the interaction between a streptococcal surface protein antigen and human salivary agglutinin. J Biol Chem 2001;276(21):18060-18065

18 Moynihan PJ, Ferrier S, Jenkins GN. The cariostatic potential of cheese: cooked cheese-containing meals increase plaque calcium concentration. Br Dent J 1999;187(12):664-667

19 Sönmez IS, Aras S. Effect of white cheese and sugarless yoghurt on dental plaque acidogenicity. Caries Res 2007;41(03):208-211

20 Bowen WH, Pearson SK. Effect of milk on cariogenesis. Caries Res 1993;27(06):461-466

21 Jensen ME, Wefel JS. Effects of processed cheese on human plaque $\mathrm{pH}$ and demineralization and remineralization. Am J Dent 1990;3(05):217-223

22 Tayab T, Rai K, Kumari V, Thomas E. Effect of chewing paneer and cheese on salivary acidogenicity: a comparative study. Int J Clin Pediatr Dent 2012;5(01):20-24

23 Schüpbach P, Neeser JR, Golliard M, Rouvet M, Guggenheim B. Incorporation of caseinoglycomacropeptide and caseinophosphopeptide into the salivary pellicle inhibits adherence of mutans streptococci. J Dent Res 1996;75(10):1779-1788

24 Philip N, Walsh L. The potential ecological effects of casein phosphopeptide-amorphous calcium phosphate in dental caries prevention. Aust Dent J 2019;64(01):66-71

25 Hegde AM, Naik N, Kumari S. Comparison of salivary calcium, phosphate and alkaline phosphatase levels in children with early childhood caries after administration of milk, cheese and GC tooth mousse: an in vivo study. J Clin Pediatr Dent 2014;38(04): 318-325

26 Weinsier RL, Krumdieck CL. Dairy foods and bone health: examination of the evidence. Am J Clin Nutr 2000;72(03):681-689

27 Sreebny LM. Saliva in health and disease: an appraisal and update. Int Dent J 2000;50(03):140-161

28 de Sousa ET, Lima-Holanda AT, Nobre-Dos-Santos M. Changes in the salivary electrolytic dynamic after sucrose exposure in children with early childhood caries. Sci Rep 2020;10(01):4146

29 Higham SM, Edgar WM. Effects of Parafilm and cheese chewing on human dental plaque pH and metabolism. Caries Res 1989;23 (01):42-48

30 Somaraj V, Shenoy RP, Panchmal GS, Jodalli PS, Sonde L, Nagaraj K. Effect of paneer and cheese consumption on salivary acidogenicity and calcium concentration: a comparative study. Oral Health Prev Dent 2018;16(02):169-174

31 Sungkar S, Chismirina S, Nasution AI, Imaduddin HK. The effect of cheese and milk on buffering capacity of saliva in children 10-12 years. JBBBE 2020;48:105-110

32 Ravishankar TL, Yadav V, Tangade PS, Tirth A, Chaitra TR. Effect of consuming different dairy products on calcium, phosphorus and $\mathrm{pH}$ levels of human dental plaque: a comparative study. Eur Arch Paediatr Dent 2012;13(03):144-148

33 Pandey P, Reddy NV, Rao VA, Saxena A, Chaudhary CP. Estimation of salivary flow rate, $\mathrm{pH}$, buffer capacity, calcium, total protein content and total antioxidant capacity in relation to dental caries severity, age and gender. Contemp Clin Dent 2015;6(Suppl 1):S65-S71

34 Kashket S, DePaola DP. Cheese consumption and the development and progression of dental caries. Nutr Rev 2002;60(04):97-103

35 Pandey RK, Tripathi A, Chandra S, Pandey A. Relation of salivary phosphorus and alkaline phosphatase to the incidence of dental caries in children. J Pedod 1990;14(03):144-146

36 Gandhy M, Damle SG. Relation of salivary inorganic phosphorus and alkaline phosphatase to the dental caries status in children. J Indian Soc Pedod Prev Dent 2003;21(04):135-138 
TAC of Saliva after the Consumption of Candies and Paneer Shah et al.

37 Vahedi M, Davoodi P, Goodarzi M, et al. Comparison of salivary ion activity product for hydroxyapatite (IPHA), alkaline phosphatase and buffering capacity of adults according to age and caries severity. J Dent 2012;13(04):139-145
38 Mohammed IJ, Sarhatb ER, Hamied MA, Sarhat TR. Assessment of salivary interleukin (IL)-6, IL-10, oxidative stress, antioxidant status, $\mathrm{pH}$, and flow rate in dental caries experience patients in Tikrit Province. Sys Rev Pharm 2021;12(01):55-59 